\title{
Glucagon-like peptide-1 does not have a role in hepatic carbohydrate metabolism
}

\author{
M. Ghiglione ${ }^{1}$, E. Blazquez ${ }^{2}$, L.O. Uttenthal ${ }^{1}$, J.G. de Diego ${ }^{2}$, E. Alvarez ${ }^{2}$, S. K. George ${ }^{1}$ and S. R. Bloom ${ }^{1}$ \\ ${ }^{1}$ Department of Medicine, Royal Postgraduate Medical School, Hammersmith Hospital, London, UK and \\ ${ }^{2}$ Departamento de Fisiologia, Facultad de Medicina, Universidad de Salamanca, Salamanca, Spain
}

Summary. Glucagon-like peptide-1 does not have specific, high-affinity receptors on rat liver membranes, does not displace glucagon from glucagon receptors on these membranes and does not stimulate the production of cyclic AMP by isolated rat hepatocytes. In the presence of glucagon, high concentrations of glucagon-like peptide-1 do not significantly al- ter the production of cyclic AMP. Thus, glucagon-like peptide-1 appears unlikely to have a direct action on hepatic carbohydrate metabolism.

Key words: Glucagon-like peptide-1, glucagon, specific receptors, cyclic AMP, liver cells.
Glucagon-like peptide-1 (GLP-1) is one of two glucagon-like peptide sequences present in the C-terminal region of the deduced sequence of mammalian pre-proglucagon [1]. Its amino-acid sequence, completely conserved between hamster [1], man [2], ox [3] and rat [4], presents a homology of 14 out of the 29 residues comparable with glucagon. It is present in extracts of human pancreas, although larger molecular forms predominate, and in glucagon-producing pancreatic tumours [5]. We have recently shown that GLP-1 does not have a glucagon-like effect on plasma glucose in cortisone-pretreated rabbits [6], whilst others have demonstrated that GLP-1-(1-36)-peptide amide and human GLP-2 activate rat hypothalamic and pituitary adenylate cyclase [7]. In order to investigate further a possible role of GLP-1 in glucose metabolism, we have looked for evidence of specific, high-affinity GLP-1 receptors on rat liver membranes. We have also investigated whether GLP-1 was capable of stimulating cyclic AMP production in isolated rat hepatocytes. As the GLP-1 sequence ends with a glycine residue as a possible donor for $\mathrm{C}$ terminal amidation [8], both synthetic GLP-1-(1-37) and synthetic GLP-1-(1-36)-peptide amide were studied.

\section{Materials and methods}

Synthetic GLP-1-(1-36)-peptide amide was purchased from Peninsula Laboratories Inc., Belmont, CA, USA, and synthetic GLP-1-(1-37) from Bachem, Torrance, CA, USA. ${ }^{125}$ I-GLP-1-(1-37) was prepared by iodination with carrier-free $\mathrm{Na}^{125} \mathrm{I}$ (IMS.30, Amersham International, Amersham, UK) using the chloramine-T method [9]. The iodinated peptide was separated from both unreacted iodine and unlabelled peptide by reverse-phase high pressure liquid chromatography on a Techsil $5 \mu \mathrm{m}$ particle size octadecylsilylsilica column eluted with acetonitrile: water: trifluoroacetic acid $450: 550: 1$ by volume. The labelled GLP-1-(1-37) showed a specific activity of $26 \mathrm{~Bq} / \mathrm{fmol}$.

The preparation of mono- ${ }^{125} \mathrm{I}$-glucagon, partially purified rat liver membranes and isolated rat hepatocytes, as well as the measurement of peptide binding to liver membranes and the production of cyclic AMP by rat hepatocytes, were carried out as described previously [10].
For the measurement of peptide binding to liver membranes, the membranes $(4150-4850 \mu \mathrm{g}$ protein per $\mathrm{ml})$ were incubated in Krebs Ringer phosphate buffer [10], $\mathrm{pH} 7.5$, containing $10 \mathrm{~g} / \mathrm{l}$ bovine serum albumin (BSA) with different concentrations of unlabelled glucagon, GLP-1-(1-37) or GLP-1-(1-36)-peptide amide and a constant concentration of mono- ${ }^{125} \mathrm{I}$-glucagon $(0.188 \mathrm{pmol} / \mathrm{ml})$ or ${ }^{125} \mathrm{I}$-GLP-1-(1-37) $(0.85 \mathrm{pmol} / \mathrm{ml})$ for $4 \mathrm{~h}$ at $10^{\circ} \mathrm{C}$. These conditions have been shown to give optimal specific ${ }^{125}$ I-glucagon binding [10]. At the end of the incubation period, the samples (total volume $250 \mu \mathrm{ll}$ ) were diluted out rapidly with $1 \mathrm{ml}$ of ice-chilled buffer and immediately filtered on Oxoid filters $(0.45 \mu \mathrm{m}$ pore-size) soaked in Krebs Ringer phosphate buffer containing $100 \mathrm{~g} / 1 \mathrm{BSA}$ for at least $1 \mathrm{~h}$ before use. Non-specific adsorption of ${ }^{125} \mathrm{I}$-glucagon to the membranes was determined in the presence of $1 \times 10^{-6} \mathrm{~mol} / 1$ unlabelled glucagon.

The isolated hepatocytes were prepared from 48 -h-fasted male Wistar rats by collagenase perfusion [10]. The cells $\left(7.5 \times 10^{6} / \mathrm{ml}\right)$ were incubated at $37^{\circ} \mathrm{C}$ for $2.5 \mathrm{~min}$ with Krebs Ringer bicarbonate [10], $\mathrm{pH} 7.4$, containing $10 \mathrm{mmol} / 1$ alanine, $2 \mathrm{mmol} / 1$ theophylline and $40 \mathrm{~g} / 1$ BSA. GLP-1-(1-37), GLP-1-(1-36)-peptide amide or glucagon were added at different concentrations in a total volume of $500 \mu \mathrm{l}$. At the end of the incubation period, the cell suspensions were treated twice with $0.5 \mathrm{ml}$ of $100 \mathrm{~g} / \mathrm{l}$ trichloroacetic acid, and the combined supernatants were washed with ether saturated with water.

Cyclic AMP was assayed by radioimmunoassay (Rianen cAMP [25 I] RIA Kit, New England Nuclear Chemicals, Dreieich, FRG).

\section{Results}

Under the conditions of incubation and separation, non-specific binding of ${ }^{125} \mathrm{I}$-glucagon was less than $2 \%$ of the total added. While unlabelled glucagon caused $50 \%$ displacement of ${ }^{125} \mathrm{I}$-glucagon $\left(\mathrm{ED}_{50}\right)$ from its specific receptors at a concentration of $3 \times 10^{-9} \mathrm{~mol} / \mathrm{l}$, neither GLP-1-(1-37) nor GLP-1-(1-36)-peptide amide at concentrations up to $10^{-6} \mathrm{~mol} / 1$ displaced ${ }^{125} \mathrm{I}$-glucagon (Fig. 1, upper panel).

When the liver membranes were incubated in the presence of ${ }^{125} \mathrm{I}$-GLP-1-(1-37) at a concentration of 0.85 $\times 10^{-9} \mathrm{~mol} / \mathrm{l}$, there was no displaceable binding of peptide to the membranes. Non-specific binding (in the presence of $2.4 \times 10^{-7} \mathrm{~mol} / \mathrm{l}$ unlabelled peptide) was $3.2 \%$ of the total tracer added.

Figure 1, lower panel, shows the effect of glucagon, GLP-1-(1-37) and GLP-1-(1-36)-peptide amide on the 

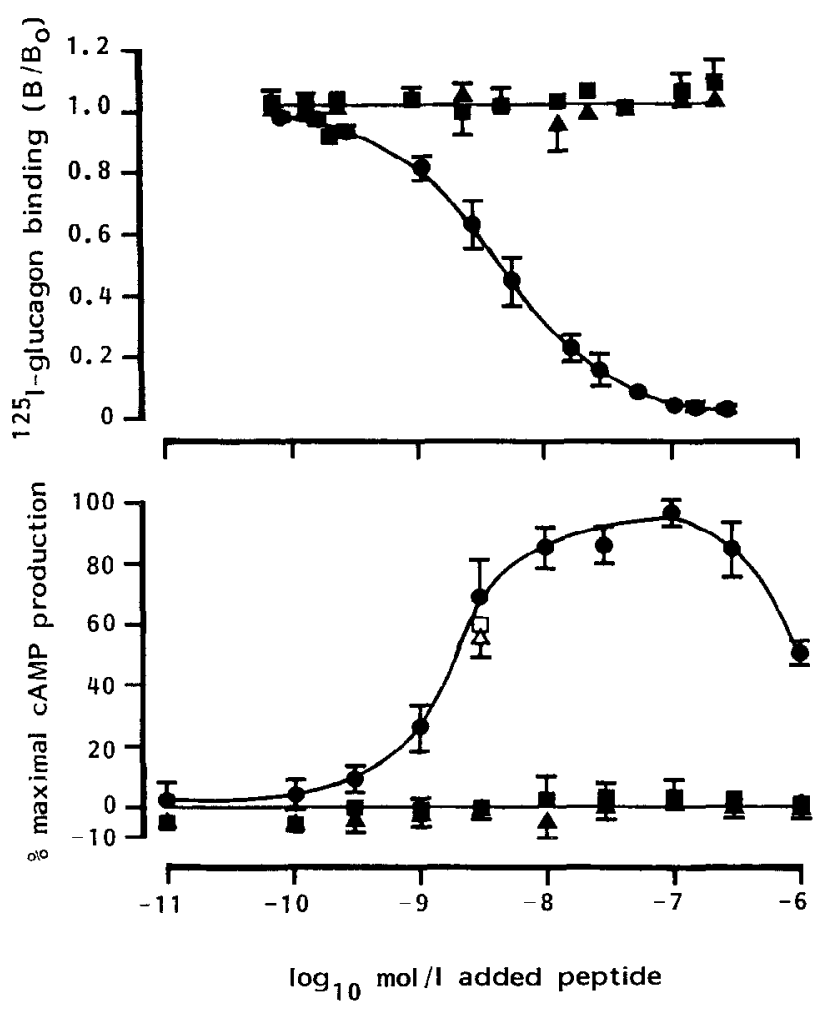

Fig. 1 Upper panel: displacement of ${ }^{125}$ I-glucagon from liver membranes by unlabelled glucagon (-), GLP-1-(1-37) ( ) or GLP1-(1-36)-peptide amide $(\mathbf{A}) . \mathrm{B} / \mathrm{B}_{0}$ is [tracer bound]/[tracer bound in absence of added peptide]. Lower panel: production of cyclic AMP by isolated rat hepatocytes in the presence of glucagon (-), GLP1-(1-37) ( $)$ or GLP-1-(1-36)-peptide amide ( 4 ), expressed as percentage of maximum increment produced by glucagon. Effect of adding GLP-1-(1-37) ( $\square)$ or GLP-1-(1-36)-peptide amide $(\Delta)$ at $10^{-6} \mathrm{~mol} / \mathrm{l}$ in the presence of glucagon $3 \times 10^{-9} \mathrm{~mol} / 1$

production of cyclic AMP by isolated liver cells. While glucagon stimulated the production of cyclic AMP over the same concentration range and with the same $\mathrm{ED}_{50}$ $\left(3 \times 10^{-9} \mathrm{~mol} / \mathrm{l}\right)$ as for its interaction with specific glucagon receptors, neither GLP-1-(1-37) nor GLP1-(1-36)-peptide amide stimulated cyclic AMP production. When the hepatocytes were incubated with $3 \times$ $10^{-9} \mathrm{~mol} / 1$ glucagon together with either GLP-1-(1-37) or GLP-1-(1-36)-peptide amide at $10^{-7}$ and $10^{-6} \mathrm{~mol} / 1$, the addition of the GLP-1 did not alter glucagon-stimulated production of cyclic AMP.

\section{Discussion}

The fact that GLP-1 does not interact with glucagon receptors in rat liver membranes is in accordance with a previous report [7], and the absence of specific, high-affinity GLP-1 receptors in these membranes suggests that the liver is not a target organ for GLP-1. This is confirmed by the finding that GLP-1 does not stimulate cyclic AMP production by isolated hepatocytes, and does not affect glucagon-stimulated cyclic AMP production. It is, of course, possible that the incubation conditions required to demonstrate specific hepatic receptors for GLP-1 differ somewhat from those producing optimal specific binding of ${ }^{125} \mathrm{I}$-glucagon label. However, the results obtained are consistent with its lack of effect on plasma glucose concentrations at high doses in vivo [6]. Furthermore, the pancreas only produces small amounts of free GLP-1 [5]. All these data suggest that, despite its structural similarity with glucagon, the highly conserved GLP-1 must have a different biological role which would not include a direct action on hepatic carbohydrate metabolism. An intra-pancreatic or enteroinsular role for GLP-1 has been postulated on the basis of its glucose dependent insulinotropic action on isolated rat islets [11]. However, receptors for GLP-1 have not yet been identified in endocrine pancreatic tissue. The evolutionary constraint that has conserved the structure of GLP-1 as completely as that of glucagon must arise from a physiological action that remains to be discovered.

Acknowledgements. This work was partially supported by grants from the Spanish Ministerio de Educacion y Ciencia (MG) and by the Medical Research Council of Great Britain (LOU and SKG).

\section{References}

1. Bell GI, Santerre RF, Mullenbach GT (1983) Hamster preproglucagon contains the sequence of glucagon and two related peptides. Nature 302: 716-718

2. Bell GI, Sanchez-Pescador R, Laybourn PJ, Najarian RC (1983) Exon duplication and divergence in the human preproglucagon gene. Nature 304: 368-371

3. Lopez LC, Frazier ML, Su C-J, Kumar A, Saunders GF (1983) Mammalian pancreatic preproglucagon contains three glucagonrelated peptides. Proc Natl Acad Sci USA 80: 5485-5489

4. Heinrich G, Gros P, Habener JF (1984) Glucagon gene sequence. Four of six exons encode separate functional domains of rat preproglucagon. J Biol Chem 259: 14082-14087

5. Uttenthal LO, Ghiglione M, George SK, Bloom SR (1984) Posttranslational processing of proglucagon in man. Regul Pept 9:351 (Abstract)

6. Ghiglione M, Uttenthal LO, George SK, Bloom SR (1984) How glucagon-like is glucagon-like peptide-1? Diabetologia 27: $599-600$

7. Hoosein NM, Gurd RS (1984) Human glucagon-like peptides 1 and 2 activate rat brain adenylate cyclase. FEBS Lett 178: 83-86

8. Bradbury AF, Finnie MDA, Smyth DG (1982) Mechanism of C-terminal amide formation by pituitary enzymes. Nature 298: 686-688

9. Greenwood FC, Hunter WM, Glover JS (1963) The preparation of ${ }^{131}$ I-labelled human growth hormone of high specific radioactivity. Biochem J 89: 114-123

10. Santos A, Blazquez E (1982) Regulatory effect of glucagon on its own receptor concentration and target-cell sensitivity in the rat. Diabetologia 22: 362-371

11. Schmidt WE, Siegel EG, Creutzfeldt W (1984) Glucagon-like peptide-1 but not glucagon-like peptide-2 augments glucose induced insulin release in isolated rat pancreatic islets. Diabetologia 27: 328A (Abstract)

Received: 15 July 1985

and in revised form: 15 October 1985

Professor S. R. Bloom

Second Floor, Francis Fraser Laboratory

Department of Medicine

Royal Postgraduate Medical School

Du Cane Road

London W12 OHS

UK 